\title{
USE OF EPORTFOLIO TOOL FOR REFLECTION IN ENGINEERING DESIGN
}

\author{
Ryan Clemmer $^{l} *$, Jennifer Spencer ${ }^{1}$, Dale Lackeyram ${ }^{2}$, Jason Thompson ${ }^{2}$, Bahram Gharabaghi ${ }^{1}$, Jonathan \\ VanderSteen ${ }^{l}$, John Donald ${ }^{l}$, and Richard G. Zytner ${ }^{l}$ \\ ${ }^{1}$ School of Engineering and ${ }^{2}$ Open Learning, University of Guelph \\ *rclemmer@uoguelph.ca
}

\begin{abstract}
Electronic portfolios (ePortfolios) can be a beneficial tool to facilitate student learning, evaluate learning outcomes and showcase skills and experience. At the University of Guelph, the School of Engineering piloted the use of ePortfolios within the third year design course of the engineering design sequence of courses. With the implementation of graduate attributes by the CEAB, more "soft skill" attributes like individual and teamwork, project management, and lifelong learning are important skills developed by students within the design courses and can be assessed within an ePortfolio environment.

Students submitted guided reflections related to major deliverables within the course. The reflections were assessed for the level of insight through rubrics in the learning management system. Overall, students improved their ability to reflect and provided good insight into their learning and roles within their group project. The response to the reflections by students was mixed. Many students found value in reflecting on their experience while other students were frustrated by the method of filling the reflection form.

In the future, the objectives for reflection should be made clearer with supplementary documentation to the lecture material. Adjusting the timing of the reflections to correspond to less stressful periods of the semester and improving the ePortfolio process will help with student engagement.
\end{abstract}

Keywords: ePortfolio, Engineering Design, Reflection, Graduate Attributes, Life-Long Learning, Project Management, Individual \& Teamwork

\section{INTRODUCTION}

Traditionally, paper-based portfolios are used to showcase student work in the fields of fine arts, architecture and teacher education. Electronic portfolios, or ePortfolios, can be used to showcase student work without the physical limitations of a paper-based portfolio and act as an educational tool to facilitate student learning, evaluate program learning outcomes, and showcase skills and experience for employability. The cross-curricular aspect of an ePortfolio also allows students to see their progression of work from the start of a program through to its completion.

The benefits of incorporating ePortfolios into the curriculum are derived from the intentional opportunities for students to reflect on their learning and to develop connections between tasks and competency development [1]. In building an ePortfolio, students have creative freedom to represent the connection between theory and practice and an opportunity to relate curricular tasks to competency development [1,2]. Reflecting on learning during the creation of an ePortfolio at different points in a curriculum has helped students in their understanding of how they learn, how they set personal goals, and their identification of lifelong learning derived from their learning experiences [3]. Fundamental to examining the development of lifelong learning skills and students' awareness of how they learn, is their ability to develop and utilize reflective skills during their program [4,5]. From a program perspective, the reflection on an ePortfolio provides a valuable opportunity to examine the growth and development of students' knowledge, skills, values and abilities over time [6]. With this understanding, program curriculum can be set to enhance program strengths and improve upon program weaknesses in terms of desired student learning outcomes.

In the School of Engineering at the University of Guelph, there is a sequence of core interdisciplinary design courses from first to fourth year. The design course sequence integrates all aspects of the design process including problem identification, analysis, synthesis, communication and reporting with mathematics, science, engineering science and complementary studies through a series of design projects. Typically, these design courses involve openended multidisciplinary design projects for teams of 3 to 5 students. New design tools are introduced throughout the 
design sequence along with information on safety, reliability, codes and standards, economic considerations and environmental concerns. Many of these topics are a focus of the new Canadian Engineering Accreditation Board (CEAB) graduate attributes (GA). The challenge going forward is assessing the quality of the program based on the strength of the student's graduate attributes upon completion of the program and making curriculum changes to improve the program. Further to this, more "soft skill" attributes like individual and teamwork, project management, and lifelong learning can be assessed within an ePortfolio environment.

A pilot project began in January 2015 within the third year design course (ENGG 3100: Engineering Design III) to test the use of ePortfolios for assessing the individual and teamwork, project management, and lifelong learning graduate attributes. Students submitted guided reflections related to major deliverables within the course such as the proposal, preliminary design report, and final design report. Within these reflections, students described their roles within their teams, how they planned to tackle the design problem, what ideas and strategies worked in managing the group and project, and how they will apply what they learned during this course to their capstone design course. These reflections were assessed for the level of insight through rubrics in the learning management system, CourseLink (Desire2Learn's Brightspace). Overall, student engagement in the process was mixed and greatly influenced by the delivery of the reflection process but many saw the value in the reflection process.

\section{REFLECTIONS IN ENGINEERING}

\subsection{Reflection Construct}

Reflecting is an activity used to help promote deeper learning as part of an active learning strategy [7]. In this case, the goal was to have students take a more in depth look at the design process while also using a new educational tool, ePortfolio, to document their experience. The aim of student reflection is to bridge the gap between surface learning, commonly encountered in higher education today, and deeper understanding of the course material [7]. Not only do students benefit from reflecting but it also provides an opportunity for instructors to better understand how students are learning in their class and make adjustments when or if required [8]. Reflection is also an important aspect of Engineering Education since students will ultimately have to reflect on their prior engineering experience when applying to become a professional engineer.

The reflection process used for this pilot project was based on "A Taxonomy of Reflection: A Model for Critical Thinking" [9] which follows the logic of the Cognitive Domains as articulated by Bloom's Taxonomy
[10]. Specifically the categories Describe, Analyze and Evaluate (DAE) were identified as the key elements on which students should progress through the reflective process when answering the various reflection questions. A DAE reflection model was created as a visual guide for students, as shown in Figure 1, to encourage students to describe the situation, leading to an analysis of the situation, and then arriving at an evaluation of the outcome and possible next steps. This DAE progression is intended to move the student to an increasingly sophisticated, deeper level of reflection.

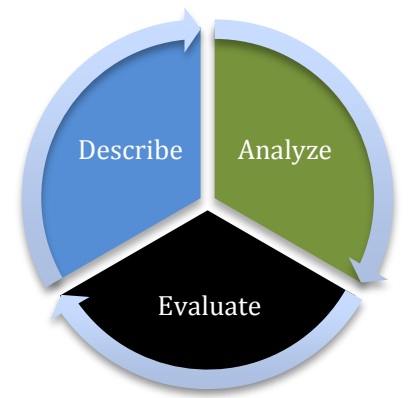

Figure 1: Describe, Analyze and Evaluate (DAE) reflection model (based on Taxonomy of reflection [9])

Students submitted guided reflections related to three major milestones within the project stages in the course: the proposal, preliminary design report, and final design report. Typically, the reflections were due a few days after submission of the course deliverable. In fostering an effective reflection process, students were asked to describe their roles and contributions within their teams, how they planned to tackle the design problem, what ideas and strategies worked in managing the team and the project, and how they will apply what they learned during this course to their fourth year capstone design course. To assist with the completion and grading of the reflections, a form was created within CourseLink for students to answer the guided reflection questions which they then submitted electronically for evaluation to the course "dropbox". The reflections were then assessed for the level of insight utilizing rubrics as shown in the appendix.

\subsection{Teaching How to Reflect}

Introducing students to the reflection activity was done in a series of lectures, one prior to the submission of each of the three reflections. The first lecture focused on introducing the concept of what a reflection is and how they are important to the students' educational development and future career. Students were instructed that a good reflection has three main components; a description that outlines what was done or who did what task, an analysis of the decision that mentions if what was done worked effectively and finally an evaluation of the 
process by understanding why the process was completed as such and if any changes should be made for future work. The three components were also used to design and build the rubric that included pre-determined feedback for the students once the reflections were marked.

To ensure students could relate the reflection activities to specific elements of the design process, the reflection questions were designed to focus on three specific graduate attributes; project management, team work and lifelong learning. The questions surrounding project management and teamwork were prepared for all three reflections and focused on elements of the design process that would be encountered prior to submitting the forms. However, the lifelong learning questions were not introduced until the final reflection in an attempt to have students recall the learning experience as a whole for the course. The reason behind selecting these three attributes as the focus of the reflections was based on the fact that the students were working in groups on a design project of their choosing throughout the semester. One objective of the reflection process was to encourage students to think about their role within the design team and how they can make an effective contribution to their design project. Requiring the students to look back on how they handled working in a team or the development of the project provided a bridge between their work and the ability to reflect. This was made clear to the students in the lectures.

In addition, example responses outlining the description, analysis and evaluation components of the reflection and how they came together to provide a complete response were presented. Students were also given the opportunity to work through a second example as a class. Since the additional element to the reflections was utilizing the ePortfolio tool, students were given stepby-step instructions with screenshots to demonstrate how to upload their completed reflections into the system where they would be marked. Using the ePortfolio tool allows students to have access to their reflections in the fourth year design course, where they will also be required to write reflections to help with the maturation of the life-long learning process.

\subsection{Reflection Evaluation Process}

Evaluation of the reflections was done using the same three components of a reflection presented during the lectures. In order to achieve this, a rubric (See Appendix A) was designed with four levels for each question; they were termed as exceeds expectations (evaluate), meets expectations (analyze), does not meet expectations (describe) or incomplete. Points were assigned for each level so that a numerical grade could be calculated to assist with the determination of the pass or fail grade. Students did not see the points that were assigned in the marking but rather just a pass or fail and what level of expectation they received. Rubrics were prepared using CourseLink software and made for a streamlined marking process which was of particular importance when evaluating individual reflections for a class of over 270 students.

Student engagement was critical for this pilot project to be successful. However, without having prior experience with developing, implementing, and assessing student reflections, it was decided that the successful completion of the reflection would be linked to the release of a major graded item rather than giving a grade weighting to these activities. Since each reflection followed one of the three major course deliverables, the release of that grade was tied to the passing of the associated reflection. In order to complete the course, each student had to successfully complete each reflection form. The only exception to this was the first reflection, which was simply a formative assessment to give students the chance to experience reflection writing, understand the process of uploading it to their ePortfolio and be able to gather feedback to improve for the second activity. Passing reflections two and three was required to receive grades for the associated major deliverable.

Utilizing an electronic rubric allowed for consistent and concise feedback in a timely manner. The reflection submissions were evaluated as a pass or fail. Students that failed the reflection submission were expected to resubmit until a pass was attained. In most cases, students were successful upon their second attempt. Direct feedback was provided based on the student's achievement level attained within specific criteria. Furthermore, the feedback included suggestions for improvement of their achievement level with respect to either resubmission and/or for the subsequent reflection submission for the next milestone-stage. Having the feedback built into the rubric made for an efficient marking process and ensured that every student received the same message.

\section{RESULTS AND OBSERVATIONS}

\subsection{Reflection Assessment Results}

The first reflection was used to gage how successful the process was, from how well the students performed to the efficiency of marking and to discover any missing elements at any stage. Most students participated in the reflections and did well. It had been initially hoped that the majority of the students would fall within the "meets expectations" category to gage whether or not the introductory lectures conveyed the necessary message. The results did show that students performed as hoped and the majority were in the "meets expectations" scoring range. Few students had difficulty with uploading the form into their ePortfolio and those that did were able to 
quickly correct the situation when directed to the instructional material provided.

The one observation of the first reflection that had a significant impact was the lack of care given to spelling and grammar, which was not a graded item initially. The form students used to fill out their responses did have a spell check tool; however it appeared as though several students did not care to use it, or were unaware of it. There was no grammar check tool in the reflection form, so this was up to a student's own ability to ensure grammar was satisfactory. Based on this observation, it was decided that both spelling and grammar should be marked in the next reflections to provide an incentive to hopefully improve this aspect of their communication abilities. In the lecture preceding the second reflection students were made aware of this change, including what was expected of their abilities, and how it would be marked on the rubric. The spell check tool was also highlighted in the lecture so students would be aware of it and be able to use it.

Results of the second reflection showed the same trend as the first. The majority of students were in the "meets expectations" graded category however there was a greater percentage in the "exceeds expectations" category for this reflection as compared to the first. After implementing the spelling and grammar component in the rubric there was a significant improvement in both however, there was no marked data from the first reflection to judge this beyond anecdotal evidence. Another interesting observation was the student's willingness to vocalize their frustrations more freely regarding the course, team members and the reflection process. It was surmised that this frustration was due primarily to the inundation of stress leading up to this submission as many students had midterms and major assignments due prior to Reading Week.

Compounding the frustrations for students was the discovery that the reflection forms used had character limits. To compensate, some questions were split up between two answer boxes but this caused some questions to appear redundant to the students. It was also noted that some students failed to recognize the difference between the project management and teamwork question categories when responding to the questions which seemed to increase the apparent frustration of some students. The lack of differentiation between the two categories of questions was highlighted in the final lecture for students to be made aware of.

The third reflection was written after students submitted their final design report and was due on the last day of class. Performance on this reflection was poorer than the second but marginally better than the first. This may be due to the timing of the reflection, being on the cusp of exams, or students' simply not wanting to put effort into the final submission as the design course was effectively over for the semester. Students who did poorly generally gave responses that were short, one sentence or less, with no consideration given to the method of reflection delivered in lectures.

\subsection{Student Engagement}

Overall the reflections were performed at a level that was expected. Many students preferred the pass/fail aspect of the reflection assessment, while others would have preferred grades to be assigned to the assessments. Some students did quite well, and it seemed that these students took the exercise seriously, finding it quite beneficial. There were some students who expressed their dislike of the activity suggesting that it was "busy" work and nothing more. This was the same sentiment engineering students had towards reflections in the study conducted by Dannels et al. [11] in a design course. In addition to the reflections, students were also responsible for maintaining a group design blog during the course. The combination of website monitoring and reflection writing may have contributed to some students experiencing assessment fatigue.

Regardless of the views towards the reflection activity itself, information regarding the workings of the course was collected that can benefit future design courses. This information included items such as; what project management and team work skills are lacking and what skills were gained, students realization of how important written communication is for engineering and the time commitment required to go through the design process. All these items can be addressed for future cohorts, to improve the course and increase the knowledge students take with them into their final year.

Preparing and executing the reflections for the third year design course was a learning experience on its own. Developing questions, rubrics, feedback forms and lectures have provided a good starting place for future reflection activities in design courses. Specifically, this information will be used as the stepping-stone into the fourth year design course where the students will be required to complete reflections once again.

\section{CONCLUSIONS \& FUTURE WORK}

The findings of this project indicate that most students were willing to undertake the task of writing reflections. However, further work can be done to emphasize their importance for deepening the educational experience in design. Providing additional documentation specifying this importance and clearly stating the reflection questions and rubrics would help to communicate the purpose of the reflection process beyond a couple of lectures. It was encouraging that the reflections generally improved from the first one, indicating that the feedback and lectures may have been helpful. With the increased stress at the end of the semester, the timing of the third reflection piece may 
have resulted in the decreased effort observed in this form. The timing of the reflections and student work load will need to be reassessed.

Students used the second reflection form as means to discuss problems with their group dynamic, as guided by the questions. As students seemed very willing to discuss problems regarding group members in this manner the reflections could be further utilized to help teaching assistants facilitate discussions on solving these problems if they are not mentioned in weekly seminars. Groups experiencing difficulty seemed to benefit more from the reflections. The third reflection provided a good resource for the team work and project management skills students felt they already had, needed more information on, or were lacking all together. This information will provide a good basis for instructors to make changes in future design courses to accommodate these needs.

Moving forward, the information contained in the ePortfolio and the ability to accurately reflect on engineering experiences is a skill that will be beneficial to the students when applying for their professional designation. Engineering regulators require information on past experiences when applying for their license and the ability to reflect on life-time learning is important.

In conclusion, the reflection exercises proved to be a beneficial step towards students taking a more active responsibility for their education when examining the three graduate attributes that were focused on. The facilitators of this exercise have been able to gather important information for continuing this endeavor in future cohorts and adapt the process to meet the needs of the students. Should the reflection process be applied across the entire design stream, there is an opportunity for students to improve upon their project management, teamwork, and lifelong learning skills.

\section{References}

[1] Oakley, G., Pegrum, M., \& Johnston, S. (2014). Introducing e-portfolios to pre-service teachers as tools for reflection and growth: Lessons learnt. Asia-Pacific Journal of Teacher Education, 42(1), 36-50.

doi:10.1080/1359866X.2013.854860

[2] Adamy, P. (2004). Strategies for enhancing assessment with electronic portfolios. Journal of Computing in Higher Education, 15(2), 85-97.

[3] Tzeng, J., \& Chen, S. (2012). College students' intentions to use E-portfolios: From the perspectives of careercommitment status and weblog-publication behaviours. British Journal of Educational Technology, 43(1), 163-176.

[4] Chambers, N. (1999). Close encounters: the use of critical reflective analysis as an evalution tool in teaching and learning. Journal of Advanced Nursing, 29, 950-957.
[5] Coleman, K., Cox, J., Das, M., Flood, A., Polly, P., Thai, T., \& Yang, J.L. (2012). Eportfolios in the Sciences: The Role of Reflection as students build professional skills and career readiness. In M. Brown, M. Hartnett \& T. Stewart (Eds), Future challenges, sustainable futures. In proceedings ascilite Wellington 2012. 219-222.

[6] Barrett, H. C. (2007). Researching electronic portfolios and learner engagement: The REFLECT initiative. Journal of Adolescent \& Adult Literacy, 50(6), 436-449.

[7] Michael Reynolds. "Reflective practice: origins and interpretations." Action Learning: Research and Practice. vol. 8. no. 1. pp. 5-13. 2011.

[8] Stephen Brookfield, S. "Critically Reflective Practice." The Journal of Continuing Education in the Health Professions, vol. 18. pp. 197-205. 1998.

[9] Peter Pappas. A Taxonomy of Reflection: Critical Thinking For Students, Teachers, and Principals (Part 1). $<$ http://www.peterpappas.com/2010/01/taxonomyreflection-critical-thinking-students-teachersprincipals.html> January 2010. Accessed January 2015.

[10] Bloom, B. S. (ed.). Taxonomy of Educational Objectives. Vol. 1: Cognitive Domain. New York: McKay, 1956.

[11] Deanna P. Dannels, Chris M. Anon, Lisa Bullard and Steven Peretti. "Challenges in Learning Communication Skills in Chemical Engineering." Communication Education. vol. 52. no. 1. pp 50-56.

\section{APPENDIX A: REFLECTION RUBRICS}

\section{Table A.1: Reflection \#1 Rubric}

\begin{tabular}{|c|c|c|c|}
\hline Question & Evaluation (3) & Analysis (2) & Description (1) \\
\hline $\begin{array}{l}\text { Why was this project } \\
\text { chosen? }\end{array}$ & $\begin{array}{l}\text { Description of the project provided. } \\
\text { Pros and cons explained. Student can } \\
\text { either relate to the importance of } \\
\text { potential project outcomes and/or } \\
\text { some degree of excitement about } \\
\text { doing the project. }\end{array}$ & $\begin{array}{l}\text { Description of the } \\
\text { project provided. Pros } \\
\text { and cons explained. }\end{array}$ & $\begin{array}{l}\text { Description of } \\
\text { the project } \\
\text { provided. }\end{array}$ \\
\hline $\begin{array}{l}\text { What project } \\
\text { management skills } \\
\text { do you think will be } \\
\text { needed to keep the } \\
\text { project on course? }\end{array}$ & $\begin{array}{l}\text { A list of skills provided. Strategies to } \\
\text { be used are provided e.g. tools like } \\
\text { Gantt charts etc. Ability to forecast or } \\
\text { predict skills that might be needed or } \\
\text { that are lacking. Identify ways of } \\
\text { evaluating any processes utilized. } \\
\text { Project scope described and related to } \\
\text { the structure of the project }\end{array}$ & $\begin{array}{l}\text { A list of skills provided. } \\
\text { Strategies to be used } \\
\text { are provided e.g. tools } \\
\text { like Gantt charts etc. } \\
\text { Project scope } \\
\text { discussed }\end{array}$ & $\begin{array}{l}\text { A list of skills } \\
\text { provided. }\end{array}$ \\
\hline $\begin{array}{l}\text { What are the } \\
\text { strengths in your } \\
\text { team that will help } \\
\text { you achieve your } \\
\text { project goals? }\end{array}$ & $\begin{array}{l}\text { List of people assigned to roles and } \\
\text { any processes that might be used to } \\
\text { enhance team efficiency or } \\
\text { effectiveness. } \\
\text { Ability to demonstrate growth and skill } \\
\text { development in team by people } \\
\text { adopting different roles i.e. why people } \\
\text { took on specific roles. Ability to } \\
\text { address why the project goal is being } \\
\text { achieved or not and what can be } \\
\text { continued or done to improve the } \\
\text { situation. }\end{array}$ & $\begin{array}{l}\text { List of people assigned } \\
\text { to roles and any } \\
\text { processes that might } \\
\text { be used to enhance } \\
\text { team efficiency or } \\
\text { effectiveness }\end{array}$ & $\begin{array}{l}\text { List of people } \\
\text { assigned to } \\
\text { roles }\end{array}$ \\
\hline $\begin{array}{l}\text { How will your team } \\
\text { incorporate the } \\
\text { different engineering } \\
\text { disciplines to } \\
\text { accomplish this } \\
\text { project? }\end{array}$ & $\begin{array}{l}\text { List of people assigned to roles from } \\
\text { different disciplines. Evaluate how } \\
\text { well the group is working based on the } \\
\text { contributions of the different disciplines } \\
\text { i.e. identify pros and cons etc. and } \\
\text { relate to how this can contribute to the } \\
\text { project goal. }\end{array}$ & $\begin{array}{l}\text { List of people assigned } \\
\text { to roles from different } \\
\text { disciplines. Discuss } \\
\text { the pros and cons that } \\
\text { each discipline brings } \\
\text { to the project. }\end{array}$ & $\begin{array}{l}\text { List of people } \\
\text { assigned to } \\
\text { roles from } \\
\text { different } \\
\text { disciplines }\end{array}$ \\
\hline
\end{tabular}


Table A.2: Reflection \#2 Rubric

\begin{tabular}{|c|c|c|c|}
\hline Question & Evaluation (3) & Analysis (2) & Description (1) \\
\hline $\begin{array}{l}\text { How have the goals of } \\
\text { this project changed } \\
\text { since you started? }\end{array}$ & $\begin{array}{l}\text { Description of changes made to } \\
\text { scope and why. Discussion of } \\
\text { implications from previous } \\
\text { decisions that led to this change. } \\
\text { Ability to forecast how these } \\
\text { changes will impact the next } \\
\text { phase of design process and any } \\
\text { outcomes. }\end{array}$ & $\begin{array}{l}\text { Description of } \\
\text { changes made to } \\
\text { scope and why } \\
\text { changes were made. } \\
\text { Discussion of } \\
\text { implications from } \\
\text { previous decisions } \\
\text { that led to this change. }\end{array}$ & $\begin{array}{l}\text { Description of goals } \\
\text { and any changes. }\end{array}$ \\
\hline $\begin{array}{l}\text { How has your group, or } \\
\text { you as an individual, } \\
\text { managed your time to } \\
\text { keep the project moving } \\
\text { forward to meet the } \\
\text { deadlines? Are there any } \\
\text { changes you would } \\
\text { make for the next phase } \\
\text { of the project? }\end{array}$ & $\begin{array}{l}\text { Discussion of time management } \\
\text { tools being used and how they are } \\
\text { effective for achieving the } \\
\text { deadlines. Discusss changes } \\
\text { being made for time management } \\
\text { within the group and any issues } \\
\text { meeting deadlines and what can } \\
\text { be done to correct this. Ability to } \\
\text { forecast how changes will benefit } \\
\text { the project. }\end{array}$ & $\begin{array}{l}\text { Discussion of time } \\
\text { management tools } \\
\text { being used and how } \\
\text { they are effective for } \\
\text { achieving the } \\
\text { deadlines. How } \\
\text { changes to be made } \\
\text { will be helpful. }\end{array}$ & $\begin{array}{l}\text { List of time } \\
\text { management tools } \\
\text { in use (Gantt chart } \\
\text { etc.). Mention } \\
\text { changes being } \\
\text { made. }\end{array}$ \\
\hline $\begin{array}{l}\text { How effective is your } \\
\text { team at accomplishing } \\
\text { the goals and tasks } \\
\text { associated with the } \\
\text { project? }\end{array}$ & $\begin{array}{l}\text { Discussion of how well team is } \\
\text { meeting goals and why the tools } \\
\text { used so far are successful. } \\
\text { Discussion of any problems with } \\
\text { meeting goals and any changes to } \\
\text { be made. } \\
\text { Ability to analyze why some } \\
\text { tools/methods worked and other } \\
\text { didn't. Discuss how the changes } \\
\text { will improve the effectiveness of } \\
\text { the team and why. }\end{array}$ & $\begin{array}{l}\text { Discussion of how well } \\
\text { team is meeting goals } \\
\text { and why the tools } \\
\text { used so far are } \\
\text { successful. } \\
\text { Discussion of any } \\
\text { problems with meeting } \\
\text { goals and any } \\
\text { changes to be made. }\end{array}$ & $\begin{array}{l}\text { State whether team } \\
\text { is meeting } \\
\text { milestones } \\
\text { effectively or not. }\end{array}$ \\
\hline $\begin{array}{l}\text { How would you describe } \\
\text { the team dynamics and } \\
\text { how do you plan to } \\
\text { utilize or change these } \\
\text { for the next phase? } \\
\text { What are the strengths } \\
\text { and weaknesses of the } \\
\text { group? }\end{array}$ & $\begin{array}{l}\text { Discuss the member dynamics } \\
\text { and how this helps or hinders the } \\
\text { team performance. List any } \\
\text { changes or concerns that should } \\
\text { be addressed. If changes are } \\
\text { needed, what are they and how } \\
\text { will they help? Able to forecast } \\
\text { how dynamics will develop } \\
\text { through the final phase of design } \\
\text { and possible outcomes due to this } \\
\text { and any proactive measures to be } \\
\text { taken. }\end{array}$ & $\begin{array}{l}\text { Discuss the member } \\
\text { dynamics and how this } \\
\text { helps or hinders the } \\
\text { team performance. } \\
\text { Why do you have this } \\
\text { dynamic? List any } \\
\text { changes or concerns } \\
\text { that should be } \\
\text { addressed. }\end{array}$ & $\begin{array}{l}\text { Describe how the } \\
\text { team works } \\
\text { together, what each } \\
\text { member brings to } \\
\text { the team, strengths } \\
\text { and weaknesses. }\end{array}$ \\
\hline Spelling & $\begin{array}{l}\text { Spelling meets expectations and } \\
\text { does not affect the clarity of your } \\
\text { sentences in your reflection. }\end{array}$ & $\begin{array}{l}\text { The frequency of } \\
\text { spelling errors is } \\
\text { affecting the clarity of } \\
\text { your sentences in your } \\
\text { reflection. }\end{array}$ & $\begin{array}{l}\text { There are } \\
\text { numerous spelling } \\
\text { errors that are } \\
\text { significantly } \\
\text { affecting the ability } \\
\text { to read the } \\
\text { sentences in your } \\
\text { reflection. } \\
\end{array}$ \\
\hline Grammar & $\begin{array}{l}\text { Grammar meets expectations and } \\
\text { does not affect the clarity of your } \\
\text { reflection. }\end{array}$ & $\begin{array}{l}\text { The frequency of } \\
\text { grammatical errors } \\
\text { distracted from the } \\
\text { message of your } \\
\text { reflection. }\end{array}$ & $\begin{array}{l}\text { There are } \\
\text { numerous } \\
\text { grammatical errors } \\
\text { that made the } \\
\text { message of your } \\
\text { reflection unclear. }\end{array}$ \\
\hline
\end{tabular}

Table A.3: Reflection \#3 Rubric

\begin{tabular}{|c|c|c|c|}
\hline Question & Evaluation (3) & Analysis (2) & Description (1) \\
\hline $\begin{array}{l}\text { PM: Based on your } \\
\text { experience with this project } \\
\text { what are the positive and } \\
\text { negative outcomes, if any? }\end{array}$ & $\begin{array}{l}\text { Description of why these } \\
\text { outcomes occurred and how } \\
\text { they impacted the project. What } \\
\text { changes could be made for a } \\
\text { more positive outcome. } \\
\text { Discussion of what tools should } \\
\text { have been used to better the } \\
\text { end result. Mention the positive } \\
\text { choices/tools etc. that led to } \\
\text { positive outcomes. How will } \\
\text { these outcomes shape your } \\
\text { future group projects? }\end{array}$ & $\begin{array}{l}\text { Description of why } \\
\text { these outcomes } \\
\text { occurred and how } \\
\text { they impacted the } \\
\text { project in either a } \\
\text { positive or negative } \\
\text { way. }\end{array}$ & $\begin{array}{l}\text { List of positive and } \\
\text { negative outcomes. }\end{array}$ \\
\hline $\begin{array}{l}\text { TW: What did you do as an } \\
\text { individual to help the team } \\
\text { function more effectively? } \\
\text { Additionally would you do } \\
\text { anything different in your } \\
\text { next group project? }\end{array}$ & $\begin{array}{l}\text { Discussion of how role } \\
\text { developed and changed over } \\
\text { the semester. Positive and } \\
\text { negative implications of this role } \\
\text { and changes to be made. How } \\
\text { will the changes improve your } \\
\text { teamwork abilities next time? } \\
\text { Discussion of things learned, } \\
\text { both to carry forward or not } \\
\text { repeat. }\end{array}$ & $\begin{array}{l}\text { List of personal role(s) } \\
\text { and discussion of how } \\
\text { role developed and } \\
\text { changed over the } \\
\text { semester. Positive } \\
\text { and negative } \\
\text { implications of this } \\
\text { role mentioned along } \\
\text { with future changes to } \\
\text { be made. }\end{array}$ & $\begin{array}{l}\text { List of personal } \\
\text { role(s) and changes } \\
\text { to be made. }\end{array}$ \\
\hline $\begin{array}{l}\text { LLL: What are some of the } \\
\text { project management } \\
\text { and//or teamwork skills that } \\
\text { you wish you had before } \\
\text { engaging in this project? } \\
\text { Specifically identify the } \\
\text { project management } \\
\text { and//ror teamwork skills that } \\
\text { would have been helpful } \\
\text { for this project? }\end{array}$ & $\begin{array}{l}\text { Able to identify skills that were } \\
\text { lacking and state why they } \\
\text { would be beneficial for } \\
\text { professional development. } \\
\text { Discuss how skills like these } \\
\text { would have improved the } \\
\text { outcome for this project or how } \\
\text { it would be used in future } \\
\text { projects. }\end{array}$ & $\begin{array}{l}\text { Able to identify skills } \\
\text { that were lacking and } \\
\text { state why they would } \\
\text { be beneficial for } \\
\text { professional } \\
\text { development. }\end{array}$ & $\begin{array}{l}\text { List of skills that are } \\
\text { lacking. }\end{array}$ \\
\hline $\begin{array}{l}\text { LLL: Identify the project } \\
\text { management and } \\
\text { teamwork skills you gained } \\
\text { and//or used for this project. } \\
\text { Specifically, explain how } \\
\text { those identified project } \\
\text { management and } \\
\text { teamwork skills you gained } \\
\text { and//or used for this project } \\
\text { contribute to your } \\
\text { engineering abilities that } \\
\text { you could utilize in the } \\
\text { future? }\end{array}$ & $\begin{array}{l}\text { Discuss why these skills were } \\
\text { helpful (or not) and how they } \\
\text { can be used for future projects. } \\
\text { List of additional skills that could } \\
\text { be useful for future } \\
\text { projects/career. }\end{array}$ & $\begin{array}{l}\text { Able to provide an } \\
\text { assessment of how } \\
\text { these skills were used } \\
\text { for this project. } \\
\text { Mention how these } \\
\text { skills will go on to } \\
\text { benefit your } \\
\text { engineering } \\
\text { ability/career. }\end{array}$ & $\begin{array}{l}\text { List of skills that } \\
\text { were beneficial for } \\
\text { the project. }\end{array}$ \\
\hline Spelling & $\begin{array}{l}\text { Spelling meets expectations } \\
\text { and does not affect the clarity of } \\
\text { your sentences in your } \\
\text { reflection. }\end{array}$ & $\begin{array}{l}\text { The frequency of } \\
\text { spelling errors is } \\
\text { affecting the clarity of } \\
\text { your sentences in } \\
\text { your reflection. }\end{array}$ & $\begin{array}{l}\text { There are } \\
\text { numerous spelling } \\
\text { errors that are } \\
\text { significantly } \\
\text { affecting the ability } \\
\text { to read the } \\
\text { sentences in your } \\
\text { reflection. }\end{array}$ \\
\hline Grammar & $\begin{array}{l}\text { Grammar meets expectations } \\
\text { and does not affect the clarity of } \\
\text { your reflection. }\end{array}$ & $\begin{array}{l}\text { The frequency of } \\
\text { grammatical errors } \\
\text { distracted from the } \\
\text { message of your } \\
\text { reflection. }\end{array}$ & $\begin{array}{l}\text { There are } \\
\text { numerous } \\
\text { grammatical errors } \\
\text { that made the } \\
\text { message of your } \\
\text { reflection unclear. }\end{array}$ \\
\hline
\end{tabular}

CEEA15; Paper 035

McMaster University; May 31 - June 3, $2015 \quad-6$ of 6 - 